\title{
Meat inspection and animal welfare practices: Evidences from north-western Himalayan region, India
}

\author{
Devesh Thakur, R K Ravikumar', Pranav Kumar², Atul Gupta, Alok Sharma, Shivani Katoch, Vinod Kumar Bodh \\ Veterinary College, CSK Himachal Pradesh Agricultural University, Palampur, Himachal Pradesh, India \\ 1. National Innovation Foundation, Ahmedabad, Gujarat, India \\ 2. Shere Kashmir University of Agriculture Science and Technology of Jammu J \& K, India \\ Corresponding author: Devesh Thakur, email:drdth4@gmail.com \\ Received: 10-05-2012, Accepted: 04-06-2012, Published Online: 29-10-2012 \\ doi: $10.5455 /$ vetworld.2012.718-722
}

\begin{abstract}
Aim: The present study was conducted to assess the animal welfare measures for safe and wholesome meat production as well to understand different roles performed by delegated institutions in ensuring quality meat production.

Materials and Methods: Semi-structured interview schedule was administered to 40 butchers and 40 veterinary officers of state department of animal husbandry, Himachal Pradesh.

Result: It was found that open slaughtering was common (87.50\%), animals did not have sufficient water provisions and often the lairage premises were devoid of adequate light thereby making ante-mortem and post mortem inspection difficult. Off feeding, offering potable water to animals before slaughtering was also less followed practice. Therefore, many a times the welfare of animals was not taken into consideration. Regular meat inspection was performed as an additional duty, by few $(22.50 \%)$ veterinarians only. It was found that veterinarian's role was restricted to meat inspection only. The issue of license for slaughtering activities was the responsibility of district administration/municipal bodies.

Conclusion: The study recommends appropriate legislations for greater role of veterinarians so as to promote quality meat hygienic practices thereby promoting animal and human welfare.

Key words: awareness, Himachal Pradesh, meat inspection measures, meat inspection trainings, veterinarian
\end{abstract}

To cite this article: Thakur D, Ravikumar RK, Kumar P, Gupta A, Sharma A, Katoch S, Bodh VK (2012) Meat inspection and animal welfare practices: Evidences from north-western Himalayan region, India, Vet World, 5(12): 718-722, doi: 10.5455/vetworld.2012.718-722

\section{I ntroduction}

Globally the incidence of food borne illness arising out of animal origin products is on the rise. Foods of animal origin (meat, eggs, milk) are one of the most important causes of human deaths worldwide as a result of contaminated food [1]. Many of the recent zoonotic infections have originated from animal or from products of animal origin [2,3]. Meat, eggs and milk are animal products that are potential source of transmission of several food borne pathogens. Meat production is still largely an unorganized activity in India. Tropical climatic conditions of India favoring microbial growth in meat, poor abattoir hygiene and sanitation measures and absence of surveillance network on meat borne diseases further increases the risk associated with meat borne zoonoses [4]. Abattoir practices more specifically inspection procedures along with welfare of animals therefore, need to be ascertained. Thus, the present study was conducted to assess the status of abattoir practices in terms of slaughtering methods/practices, meat inspection procedures as well as role of institutions in ensuring quality meat production in the state of Himachal Pradesh, India.

\section{Materials and Methods}

The present study was conducted in different agro climatic zones ( 8 districts namely Kangra, Kullu, Chamba, Shimla, Lahual \& Spiti, Hamirpur, Bilaspur and Shimla) of Himachal Pradesh, India. A semi structured interview schedule pertaining to study was developed and administered to 40 veterinarians working in these regions of the state. The information was also collected from forty meat sellers and slaughtering personnel in and around Palampur subdivision of Kangra district who were randomly selected and interviewed to supplement information from veterinary officers. Palampur subdivision was purposively selected due to ease of data collection. Field visits and personal observations were made to assess meat inspection and 
Table-1. Distribution of Butchers/Meat handlers according to meat inspection practices

\begin{tabular}{|c|c|c|}
\hline Sr. No. & Practice & Frequency of Respondents \\
\hline 1 & $\begin{array}{l}\text { Species Slaughtered } \\
\text { Small ruminants (Sheep Goat) } \\
\text { Pig }\end{array}$ & $\begin{array}{l}38(95.00) \\
2(05.00)\end{array}$ \\
\hline \multirow[t]{2}{*}{2.} & Open Slaughtering & \\
\hline & $\begin{array}{l}\text { Yes } \\
\text { No }\end{array}$ & $\begin{array}{l}35(87.50) \\
5(12.50)\end{array}$ \\
\hline \multirow[t]{2}{*}{3.} & Resting places for animals & \\
\hline & $\begin{array}{l}\text { Yes } \\
\text { No }\end{array}$ & $\begin{array}{l}37(92.50) \\
3(7.50)\end{array}$ \\
\hline \multirow[t]{2}{*}{4.} & Capacity of resting places & \\
\hline & $\begin{array}{l}\text { Less than } 40 \text { animals } \\
40-70 \text { animals }\end{array}$ & $\begin{array}{l}8(20) \\
29(72.50)\end{array}$ \\
\hline \multirow[t]{2}{*}{4.} & $\begin{array}{l}\text { More than } 70 \text { animals } \\
\text { Average space provided in resting places }\end{array}$ & $3(7.50)$ \\
\hline & $\begin{array}{l}\text { Less than } 40 \text { animals } \\
40-70 \text { animals } \\
\text { More than } 70 \text { animals }\end{array}$ & $\begin{array}{l}25 \times 10 \text { Sq. feet } \\
35 \times 15 \text { Sq. feet } \\
50 \times 20 \text { Sq. feet }\end{array}$ \\
\hline \multirow[t]{2}{*}{4.} & Ante-Mortem inspection & \\
\hline & $\begin{array}{l}\text { Yes } \\
\text { No }\end{array}$ & $\begin{array}{l}0(0.00) \\
40(100.00)\end{array}$ \\
\hline \multirow[t]{2}{*}{5.} & Post Mortem Examination by Veterinarian & \\
\hline & $\begin{array}{l}\text { Yes } \\
\text { No }\end{array}$ & $\begin{array}{l}11(27.50) \\
29(72.50)\end{array}$ \\
\hline \multirow[t]{2}{*}{6} & Slaughtering of animal in front of other animals & \\
\hline & & $\begin{array}{l}22(55.00) \\
18(45.00)\end{array}$ \\
\hline \multirow[t]{2}{*}{7} & Adequate rest preferably overnight & \\
\hline & $\begin{array}{l}\text { Yes } \\
\text { No }\end{array}$ & $\begin{array}{l}26(65.00) \\
14(35.00)\end{array}$ \\
\hline \multirow[t]{2}{*}{8} & Off feeding of animals for 24 hours prior to slaughter & \\
\hline & $\begin{array}{l}\text { Yes } \\
\text { No }\end{array}$ & $\begin{array}{l}5(12.50) \\
35(87.50)\end{array}$ \\
\hline \multirow[t]{2}{*}{9} & Offering water to animals before slaughter & \\
\hline & $\begin{array}{l}\text { Yes } \\
\text { No }\end{array}$ & $\begin{array}{l}7(17.50) \\
33(82.50)\end{array}$ \\
\hline \multirow[t]{2}{*}{10} & Protection against rodents, dogs, flies, insects & \\
\hline & Yes & $23(57.50)$ \\
\hline
\end{tabular}

handling practices of animals. Visits to slaughtering places in rural as well as urban regions were also made to assess the welfare of animal before and during the slaughtering practices.

\section{Results and Discussion}

Preferred meat species: Among all the animals slaughtered in the region, sheep and goat were the most common species of animals slaughtered in the region apart from poultry. In fewer areas, pig slaughtering was also performed (Table-1).

Slaughtering practices: Open slaughtering of animals was a common feature $(87.50 \%)$. Most common slaughtering sites were open spaces beneath bridges, local water streams, under bushes and forest areas with at least some water source for discharging the meat byproducts and waste matter. No designated slaughtering areas were marked for poultry as they were slaughtered in the shops or in the houses/surrounding areas of chicken sellers. The water from these streams was used to initially clean the carcasses which were later again cleaned at the selling outlets. Joshi et al. [5] also reported that in Nepal, in the absence of modern slaughter houses animal slaughtering was common in streets, riversides, and open pasturelands. In the Indian state of Nagaland, all town and village slaughtering places of pigs were carried in open air [6].

Resting places of animals: Relatively, high percentage $(92.50 \%)$ of butchers had resting places (not strictly lairages) for the animals. The butchers/meat Sellers purchase the animals in larger numbers ranging from 1 to more than 70 and kept them in resting places where animals were regularly grazed and slaughtered daily as per the prevailing demand. Majority $(72.50 \%)$ of the resting places had capacity of 40-70 animals with average dimensions of $35 \times 15$ Sq. feet. However, the resting spaces did not have sufficient lighting and water provisions as the animals were drinking water during daytime grazing in nearby water sources, mainly streams.

Animal slaughtering practices: Mostly, slaughtering 
Meat inspection and animal welfare practices: Evidences from north-western Himalayan region, India

Table-2. Level of co-ordination between State animal husbandry department and Municipal bodies/Panchayat/ District administration ( $\mathrm{N}=40)$

\begin{tabular}{|c|c|c|c|c|}
\hline Sr. No. & Duties/Roles performed by Veterinarian regarding Meat Inspection & In practice & Sometimes in practice & Not practiced \\
\hline 1 & Assignment of full time veterinarian for enabling meat inspection & $02(05.00)$ & $00(00.00)$ & $38(95.00)$ \\
\hline 2 & Visit to meat shops by veterinarian for inspection by themselves & $09(22.50)$ & $11(27.50)$ & $20(50.00)$ \\
\hline 3 & Request by municipal bodies /village $P$ anchayat to carry meat inspection & $07(17.50)$ & $02(05.00)$ & $31(77.50)$ \\
\hline 5 & Condemnation/Declaration of carcasses unfit for consumption. & $00(00.00)$ & $02(05.00)$ & $38(95.00)$ \\
\hline 6 & Stamping/Certification of meat for human consumption at commercial places & $07(17.50)$ & $05(12.50)$ & $28(70.00)$ \\
\hline
\end{tabular}

Figures in parenthesis indicate percentages

was done in the early hours of day as per the prevailing demand in the absence of sufficient meat storage and preservation facilities. Ante mortem inspection was altogether absent while in some instances post mortem were being performed by qualified veterinarians. Provisions of separating the animals by slaughtering from the animal to be slaughtered was lacking in all the instances. However, in some regions, fewer animal slaughtering (3-4) in a day made the possibility of killing in front of others. Practice of keeping the animals off fed before slaughter was remotely practiced $(12.57 \%)$ as butchers believed that keeping animal off-fed would reduce body weight of animals. Similarly offering of drinking water was rarely practiced $(17.50 \%)$. The measures against protection from dogs, flies and insects were also inadequate in majority of resting places as well as in the meat shops $(90 \%)$. To ensure quality meat production, meat slaughter houses must have facilities for light, ventilation for hygienic dressing of carcasses, cleaning and disinfection of utensils; light for inspection, ventilation for fresh air, removal of foul odour, wholesome water, disinfection $\&$ cleaning of utensils, instruments and hands, lighting and ventilation [7]. However, most slaughter houses in India lack basic amenities like light, ventilation, water and sanitation $[8,9]$.

Although, modernization of slaughterhouses in urban as well as rural regions should receive top priority yet socio-economic, religious impediments have denied any improvement in modernization of slaughterhouses in India [10]. The only proposed modern slaughter house in the region (Himachal Pradesh) faced stiffed opposition from local bodies [11]. Further poor handling of carcasses by meat handlers may be due to lack of awareness, illiteracy on their part [12].

Meat inspection by veterinarians: As it was evidenced in Table-2, in the majority $(95 \%)$ of instances no full time veterinarian was appointed for meat Inspection. The percent of veterinarians engaged in regular meat inspection in the region was also meager $(22.5 \%)$.Meat inspection is an additional responsibility to veterinarians in many states of India [10]. In the absence of appropriate acts and rules, meat inspection was carried as off and on activity by either veterinarian or municipality sanitation/health official in Nepal [5]. Absence of sufficient meat inspectors increases the risk of diseases transmission from slaughter houses [13].

Meat inspection activities performed by veterinarians: Meat inspection practices was restricted mainly to post mortem inspections. In majority of instances, ante mortem examination, visits to slaughtering places, other animal welfare considerations (preslaughter animal handling, off-feeding, offering drinking water etc.) were not taken into account by the veterinarians in the absence of adequate legal enforcement mechanisms.

Role of municipal bodies and district administration in meat inspection: The level of co-ordination between village panchyats/municipal bodies were observed to be low as very few times $(22.50 \%)$, the bodies had requested the veterinarian to perform meat inspection. Further, involvement of veterinarian in issuing and cancellation of license was not practiced at all in majority (95\%) of the cases. Carcass rejection and stamping of meat was therefore a rarely followed practice. Similar findings have also been reported in Nepal, where veterinarians were not responsible for meat inspection in the absence of appropriate acts and rules [5]. Regulation of slaughter houses, meat shops and tanneries is primarily the function of municipal bodies in urban regions of Himachal Pradesh [7]. The law specifies that granting and cancellation of license to meat shops/abattoirs rests with the municipal bodies. In rural regions, the corresponding authority lies with the village Panchyat/civil administration (deputy collector). Therefore, role of veterinarian is limited only up to meat inspection denying their role in issuing and cancellation of licenses which precluded their role in ensuring quality and wholesome meat production. Regular meat inspection and approval of abattoir facilities by municipal bodies in developing countries can be one of the measures to reduce the risk 
Meat inspection and animal welfare practices: Evidences from north-western Himalayan region, India

Table-3. In service Trainings to Veterinary officers on Meat inspection (2011-2012)

\begin{tabular}{llcc}
\hline Sr. No. & Training activity & Total number & Total beneficiaries \\
\hline 1 & Diseases diagnosis & 8 & 8 \\
2 & Clinical aspects & 1 & 30 \\
3 & Poultry production & 3 & 6 \\
4 & Extension Education & 1 & 30 \\
5 & Miscellaneous & 6 & 20 \\
& (e-governance, information Technology) & 0 & 0 \\
\hline
\end{tabular}

Source: Annual Training Plan 2011-2012 for In-service Veterinary Officers, State Animal husbandry Department, Himachal Pradesh

Table-4. Rank order of measures to improve the quality of animal slaughter/meat inspection

\begin{tabular}{|c|c|c|c|}
\hline Sr. No. & Suggestions for improvising quality meat inspection practices & Frequency (\%) & Rank \\
\hline $\begin{array}{l}3 \\
4 \\
5 \\
6 \\
7 \\
8 \\
9 \\
10\end{array}$ & $\begin{array}{l}\text { More involvement of veterinarians in issuing and cancellation of licenses to open slaughter houses/meat shops } \\
\text { Requirement of sensitisation training to meat handlers/butchers regarding importance of meat inspection /meat borne } \\
\text { Zoonoses faced by them. } \\
\text { Veterinary Officer should be given adequate police force while inspection. } \\
\text { It should be mandatory for veterinary officer to visit the meat shops on one fixed date of Month } \\
\text { Full time public health veterinarians are needed to be appointed for meat inspection. } \\
\text { Incentives for veterinarian to ensure meat inspection at odd hours in terms of service charge, vehicle allowance etc. } \\
\text { Training to veterinarians regarding meat inspection procedures/acts/bye laws/meat borne Zoonoses. } \\
\text { The meat seller should bring the carcass before the veterinarian. } \\
\text { Meat inspection should be supported through adequate platform tests. } \\
\text { Presentation of carcasses before selling by sellers for inspection before veterinarian. }\end{array}$ & $\begin{array}{l}40(100 \%) \\
37(93.37 \%) \\
32(80 \%) \\
31(77.67 \%) \\
25(62.50 \%) \\
23(57.50 \%) \\
22(55.00 \%) \\
15(37.67 \%) \\
13(32.50 \%) \\
15(37.67 \%)\end{array}$ & $\begin{array}{l}\text { I } \\
\text { III } \\
\text { III } \\
\text { IV } \\
\text { V } \\
\text { VI } \\
\text { VII } \\
\text { VII } \\
\text { VIII } \\
\text { X }\end{array}$ \\
\hline
\end{tabular}

Figures in parenthesis indicate percentages

of post slaughter meat contamination [14]. This may require effective co-ordination between different institutions involved in meat inspection procedures. The pivotal role of practicing veterinarians in improved meat and milk inspection led to significant reduction of prevalence of bovine tuberculosis in US [15].

Trainings and capacity building on meat acts, legislations, animal welfare and zoonoses: The awareness among the veterinarians regarding latest developments/modifications on legislations/meat acts to ensure quality meat production was observed to be low. This was also reflected in the training programmes conducted for the veterinary officers by the state department of animal husbandry. Although the state department had a well planned training calendar to its entire staff with earmarked annual budget of Rs 4.86 million for year 2011-12. However, none of the training programme was conducted on meat inspection acts, laws byelaws and on animal welfare (Table-3).

As a result, none of the veterinary officer/official had participated in any training on meat inspection, meat borne zoonoses, meat acts and bye-laws. The state department of animal husbandry is a major stakeholder in awareness generation to the farmers and livestock producers. However, majority of meat handlers in India receive training informally through family members or colleagues only [12]. Most of the butchers working in meat sector in India are not adapted to newer meat processing techniques and quality standards. Also, there is no cadre of qualified veterinarians/technicians for meat inspection in many states of India. Therefore, there is an urgent need to train butchers and meat inspectors [10]. Identification of condemned meat, meat borne diseases and their common signs, symptoms, control and prevention can be some of the areas of continuous veterinary education training programmes to veterinarians. Similarly, awareness programmes at the level of producers, meat handlers and consumers with regards to the safe handling of meat are essential [14].

Suggested measures to improve meat inspection and animal welfare practices: Rank order of measures to improve meat inspection and animal welfare measures was elucidated (Table 4 ) from 40 veterinary officers from different districts of the state of Himachal Pradesh. These measures can help in improvement in the quality of meat production in India.

\section{Conclusion}

To reduce the risk of meat borne associated diseases/poisoning inculcating hygienic slaughtering practices is foremost measure of reducing the contamination of carcasses. Further, it would also check meat borne infections among the large number of butchers and handlers of raw meat in the meat supply chain of India. Strengthening rural network of veterinarians ,adoption of new legislations giving appropriate capacities to veterinary administration and their partners can only mitigate the increased risk of zoonoses (including meat borne) in India [4]. 
Strong institutional monitoring and enforcing quality standards by the stakeholders (village panchyat, municipal bodies, veterinarians associated with meat inspection) is therefore needed to reduce the increasing risks to human health out of animal slaughtering activity .The State departments of animal husbandry should have sufficient delegated authority by district administration to carry meat inspection in the region.

\section{Author's contribution}

All authors have contributed equally. All authors read and approved the final manuscript.

\section{Acknowledgements}

The authors are thankful to the veterinary officers of State department of animal husbandry, Himachal Pradesh for providing valuable support to undertake the study.

\section{References}

1. WHO (1999) World health statistics quarterly, 50 (Nos. 1-2).

2. Woolhouse M.E. (2002) Population Biology of Emerging and remerging pathogens. Trends in Microbiology 10(10):S3:S7.

3. Sherikar, A. T., and Waskar, V. S., (2005) Emerging zoonoses and social-economic impact in India-A review. Indian JAnim Sci. 75(6):700-705.

4. Bhandare, S. G., Sherikar, A. T., Paturkar, A. M. Waskar, V. S., and Zende, R. J.,(2007) A comparison of microbial contamination on sheep/goat carcasses in a modern Indian abattoir and traditional meat shops. Food Control, 18: 854-858.

5. Joshi, D. D., Maharjan, M., Johansen, M. V., Willingham, A.L. and Sharma M.(2003) Improving Meat Inspection and Control in resource poor communities: the Nepal example. Acta Trop, 87:119-
127.

6. Fahrion A, Richa K, Jamir L, Begum S, Rutsa V, Ao S, Padmakumar V and Grace D. (2010). Risk assessment in the pork meat chain in Nagaland, India. A poster prepared for the Annual Meeting of the Society for Veterinary Epidemiology and Preventive Medicine, Nantes, France, March 24-26, UK.

7. Anonymous (1994) Rules and Regulations governing the licensing of meat Shops in Shimla. Meat inspection guidelines, municipal corporation, Shimla, Himachal Pradesh, India.

8. Kumar N and Kaul P. N. (2000) Operational Environment in a slaughter house: A Macro level case study. Indian J. Anim. Res. 34(1):1-10.

9. Kondaiah $\mathrm{N}$ and Pragati H. (2005) Meat Sector and its Development.Indian J Anim Sci. 75(12):1453-1459.

10. Planning Commission (2012) Report of the working group on animal husbandry \& dairying for 12th five year plan, Planning Commission, New Delhi, India.

11. Anonymous (2010) Modern abattoir proposed for Shimla meets opposition, Indian Express, February 3.

12. Sahay A, Tiwari R, Sharma M C and Roy R. (2011) Awareness and training needs in hygienic meat production among butchers and Meat handlers Livestock International Jan-March: 10, 11\&14.

13. Bala A. N.,Garba A E and Yazah A J. (2011) Bacterial and parasitic zoonoses encountered at slaughter in Maiduguri abattoir, Northeastern Nigeria Vet. World, 4(10):437-443.

14. Ahl A S and Sutmoller P.(1997) Contamination of Animal products: prevention and risks for public health. Rev. sci. tech. Off. int. Epiz.16(2):1-27.

15. Palmer M. V. and Waters W. R. (2011) Bovine Tuberculosis and the establishment of an Eradication Program in the United States: Role of Veterinarians. Veterinary Medicine International.(Retrieved from http://www.ncbi.nlm.nih.gov/pmc/articles/PMC3103 864/pdf/VMI2011-816345.pdf.) 